\section{A Aaprer oN}

\section{FILTERABLE VIRUSES AND PRACTICAL MEDICINE.*}

\section{S. P. BEDSON, M.D., M.Sc.,}

\author{
SENTOR FREEDOM RESEARCH FELLOW, LONDON HOSPITAL.
}

I APpreciate the invitation to open this discussion, not as a personal honour, but rather as a compliment to the laboratory worker, and an instance of that spirit of co-operation between the two branches of medicine-clinical and scientific-which is daily becoming more intimate and consequently more fruitful. There is one point that I should like to bring into prominence. The clinician, faced as he is daily with the vital problems of disease, should be, and often is, one of the great initiative forces in research. Since my appointment to a research post at the London Hospital I have come to realize how stimulating a close contact with the clinical side of medicine can be to the laboratory worker. But for this to be effective the clinician must have some conception of the lines along which the pathologist is thinking, and I feel, rightly or wrongly, that many clinicians may be out of sympathy with investigation in the field of filterable viruses as suggesting too much of what is termed academic research. I therefore welcome the opportunity of describing some aspects of recent work on this group of disease agents, and hope to show that if something of practical value has already been achieved, the future promises that the laboratory may become of even greater assistance in this realm of disease. I propose, first of all, to discuss very briefly the probable nature of these so-called filterable viruses, and then to deal with the question of immunity in diseases of this class, for it is in connexion with this latter question that much of practical import is going on.

\section{The Nature of Filterable Viruses.}

Much of the work and speculation which this intriguing problem has incited has merely heightened that.atmosphere of mystery with which the unknown is invariably surroumded. This, I think, goes a long way to explain the difficulty which the clinician has experienced in approaching the suljicet. Some have endeavoured to show that these viruses are unorganized enzrme-like agents, a contagium rivum fluidum as Beijerinck first suggested. Others, while admitting their particulate nature, consider that they represent a form of life differing from that of the cultivable bacteria. Some would even have us believe that they are the product of diseased cells, a product which when brought into contact with fresh susceptible cells gives rise to the same diseased state, and in so doing engenders more of itself, the virus thus becoming both the cause and the result of the disease. I do not deride speculation, for I recognize that it denotes a healthy and useful attitude of mind, but it is perhaps unfortunate that much" of the speculation" which this problem has called forth has served largely to cloud the issue. Surely it would have been better to start from the simpler and more obvious conception that these viruses are akin to bacteria than to evolve an ingenious hypothesis postulating a new form of life and endeavour to make observed facts support it. If one accepts a view of kinship as a working hypothesis the first question is: Are these viruses living? Now this is not such a simple matter to settle as one might imagine. The line of demarcation between the living and non-living is by no means clearly drawn; in fact, there is no single criterion of life. But there are certain characters (such as the power to multiply, to adapt to altered environment, and to assimilate from the surrounding medium without loss of individuality) which when present together arc characteristic of living things; since filterable viruses possess all these, one is justified in assuming that they are alive.

* Read in opening a discussion in the Seetion of Medicine at the Annual Meeting of the British Medical Association, Winnipeg, 1930.
Having admitted the living nature of these agents a second question demands solution; this concerns their relation to the bacteria with which we are familiar. One factor, more than any other, has tended to obscure this issue-namely, the limitations of the microscope. Using the visible portion of the spectrum, particles helow a certain size cannot be seen with the microscope; although, of course, this is a purely artificial limit it has had a profound effect on the way in which the problem of the nature of filterable viruses has been envisaged. We have become so used to staining bacteria and examining them by means of the microscope that we question the bacterial nature of a virus which does not lend itself to demonstration by the usual methods. This has led to these viruses being termed ultra-microseopic; but though some of them probably do merit that designation, there are others which are almost certainly within the limits of visibility with the microscope. The bodies described by Paschen in vaccinia virus, which many now hold with Paschen to be the virus, can be stained and seen under the microscope, and the virus of psittacosis is definitely associated with most characteristic bodies which I believe to be the virus. Another example is the virus of fowl-pox, so that there seems good reason for stating that "ultra-microscopic" is not a character common to this group of viruses. Undoubtedly they are extremely small, as is evidenced by the fact that the majority can traverse filters which hold back the ordinary bacteria, but is this a sufficient reason for marking them off as something different? I do not think so. Some of the so-called filterable viruses filter with great difficulty-vaccinia for example-and on the other hand there are visible and cultivable bacteria, such as Bacterium pneumosintes, and a number of small saprophytes in the human nasopharynx, studied by Olitsky and Gates ${ }^{1}$ and by Dochez and his colleagues, ${ }^{2}$ which pass through the more porous bacterial filters. On the score of size, then, there seems no good reason for separating these viruses from the bacteria; the one group merges imperceptibly into the other.

The inability to cultivate the so-called filterable viruses in a lifeless medium is another reason advanced for assuming that they are not bacterial in nature. For a time our only method of eultivation was in the tissues of the living animals, but the work of Steinhard and Lambert, ${ }^{3}$ Parker and Nye, ${ }^{4}$ Carrel and Rivers, ${ }^{5}$ and others, has shown that they could be made to multiply in the presence of living cells in tissue culture, and the Maitlands ${ }^{6}$ have further simplified this method of cultivation. Even though we were still unable to grow these viruses apart from living cells, I should hesitate to advance this as a reason for their being unlike bacteria, for there are visible bacteria, such as the leprosy barillus, the cultivation of which in artificial media, despite repeated attempts in the past, is only a recent achievement which awaits confirmation. Recent work by Muckenfuss and Rivers ${ }^{7}$ with the virus of vaccinia would seem to suggest, however, that the virus does not multiply either inside or at the surface of the living cells. Using Maitland's medium, which consists of rabbit's serum diluted with Tyrode's solution added to fragments of fresh tissue, they have obtained survival and possible multiplication of vaccinia virus when the living tissue was separated from the virus by means of a collodion membrane. This would suggest that the function of the living cells is to supply some diffusible substance necessary to the growth of the virus; should this work be confirmed, it may ultimately lead us to a method of artificial cultivation which would remove this apparent difference between the filterable viruses and eultivable bacteria.

No doubt there are competent authorities who will disagree with me, but in my opinion the available evidence strongly supports the view that filterable viruses are bacterial in nature. With each step forward in our knowledge of these viruses, the line of demarcation between them and the bacteria becomes less and less obvious, and I look forward with some degree of confidence to the time when the filterable viruses and bacteria will be merged into onê large group, inside which, of course, there will be slight differences-subgrouping-just as there is in the case of bacteria at the present time. 
Immunity in Virus Diseases.

It has become usual to speak of the immunity in virus diseases as being solid and long-standing, lifelong even, in contradistinction to the immunity resulting from bacterial disease, which is so often fugitive; but like most generalizations this is only partially true. Undoubtedly recovery from many filterable virus diseases is accompanied by the development of an immunity of high degree and long duration. One knows, for instance, low seldom an individual contracts diseases like measles, mumps, or yellow fever more than once. But there are diseases due to filterable viruses such as foot-and-mouth disease, herpes, and the common cold-the recent work of Dochez and his colleagues would seem to warrant the inclusion of the last disease in this category ${ }^{8}$ - in which the immunity is flecting and of low grade, just as there are bacterial diseases such as typhoid ferer which confer a good immunity. Here again the division between the two groups is not absolute.

Immunity to a bacterium is associated with the development of antibodies, the presence of which in the blood can be demonstrated in a variety of ways. Although the importance of these antibodies in ensuring the immune state varies in the different bacterial diseases, there can be no doubt that either alone or in co-operation with the phagocytic cells of the body they play an important part in the defence mechanism of the organism. This is not their only importance, for, of course, they are of the greatest service to us in diagnosis. It has been recognized for some time that immuinity to filterable virus diseases is associated with the development of specific antibodies which, from the method employed for their demonstration, have been spoken of as neutralizing antibodies. During the last few years there has been a tendency to minimize the importance of these antibodies in the vast majority of filterable virus diseases, and to speak of the immunity as being almost entirely cellular-a tissue immunity. Recent work, however, has gone a long way to controvert this view, and there seems little doubt that in filterable virus diseases, just as in those of bacterial origin, the two factors-cells and humours-work together in defending the tissues from invasion. An active immunity can be obtained against a filterable virus by methods similar to those $\mathrm{cm}-$ ployed in the case of a bacterium; a viricidal serum can be utilized to procure a passive protection, and with this serum the same immunity reactions that we are familiar with in bacterial diseases can be demonstrated. Let us consider these phenomena more closely.

\section{Active Immunization.}

There are two diseases due to filterable viruses against which prophylactic vaccination has been practised for a considerable time. I refer to small-pox and rabies. In the case of the former disease we make use of the fact that the virus of small-pox when adapted to the cow loses its invasive power for the human organism, so that when implanted in the skin it gives rise to a local lesion only, the evolution of which, however, confers immunity against the virus of small-pox. The principle involved-namely, the use of living virus which has been altered by passage through another animal species-is of limited application, for, apart from small-pox, fowl-pox is the only other example of a virus disease in which it is applicable.

Although this method of prophylactic immunization is good in that it produces a high degree of immunity, it is not without its dangers. Vaccination in Europe has been complicated of late years by an encephalomyelitis with a high mortality. It is true that the incidence of this complication is very low, about 1 in 40,000 vaccinated, or 1 in 4,000 of primary vaccinations at a susceptible age. But few though these cases are they cannot be ignored, and we must consider what steps are to be taken to avoid their occurrence.

The etiology of the condition is still under dispute, some holding that the disease of the central nervous system is the work of the virus of vaccinia, while others maintain that it is due to a dormant neurotropic virus which is stirred up by the vaccinia virus. Whichever view may be correct it would seem obvious that the occurrence of such a complication would be minimized or entirely avoided by reducing the amount of virus inserted locally in vaccinating, for the more rirus implanted in the skin the greater the amount of virus which will invade the body generally. In England this view has led the Ministry of Health to issue an order that vaccination is to be made with one insertion only, with minimal trauma, and at the Iondon Hospital we have employed dilution of the lymph. Gins also adrocates dilution of the lymph, and it is possible that in Canada the immunity from these troubles has been due in part to the fact that vaccination is less drastic than in Great Britain. By still greater attention to the question of dosaga the method might possibly be made quite safe, but, personally, I should like to see a method erolved in which inactive or dead virus was used. There are considerable difficulties to orercome, however, before such a method will be arailable.

Active immunization against rabies involves another principle-namely, the use of attenuated or inactive virus. The classical method makes use of drying to attenuate the virus, but carbolized virus is used with equally good results. For long this principle was not considered as applicable to other virus diseases, and the view that the production of lesions with living virus was an essential factor in the development of the immune state was almost universally accepted. The observation, made independently by Vallée and his colleagues ${ }^{9}$ at Alfort, and by the British Foot-and-Mouth Committee, ${ }^{10}$ that the virus of foot-andmouth disease could be rendered inactive by low concentrations of formalin and ret retain its antigenic power has put another aspect on the matter. I am not claiming that the immunity produced by inactive virus is as solid as that called forth by living virus; I do not believe that it is. But the method has its uses, and it has since been shown that vaccines can be prepared by this method from other viruses, such as fowl plague, distemper, and yellow fever. The work of Laidlaw and Dunkin, ${ }^{11}$ in the prophylaxis of distemper, has been particularly successful. They make use of two vaccines: the first an inactive formolized vaccine which produces a certain degree of immunity, which is then conrerted into a solid immunity by the second vaccino consisting of living virus. The method has already passed beyond the sphere of experiment, and has been applied in the field with manifest success.

In other disenses progress along these lines has not been so rapid. Although in France a formolized foot-andmouth vaccine has been used in the field to a limited extent, in lingland it is still in the experimental stage. In the case of this disease, however, it must be remembered that the spontaneous disease gives only a fugitive immunity, and a further complication is the cxistence of three immunologically distinct types of virus. If an attack of a disease does not confer a durable immunity one cannot hope to achieve very much by the administration of vaccines as a prophylactic measure, and this fact must be borne in mind when considering such diseases as the common cold and influenza, whero one attack appears to confer little or no resistance to subsequent ones. Thero is another observation made by Laidlaw and Dunkin in connexion with their work on distemper which puts a check on undue optimism. The supply of a filterable virus in any great quantity, at any rate at the present time, is obtained from the tissues of an infected animal. In the preparation of distemper vaccine, for instance, use is made of the tissues of an infected dog. Both the dow and the ferret are susceptible to this disease, but though a formolized ferret vaccine works admirably in the ferret it is a poor vaccine for the $\operatorname{dog}$, and vice versa; the animal tissues present in the vaccine, when foreign to the vaccinated animal, interfere with the development of immunity to the virus. It is easy to see how this will mitigate against the successful application of the method in man, at any rate for the present. I make that qualification because much will depend on the progress which we can make in the cultivation of the filterable viruses. The work of Muckenfuss and Rivers, which I have already mentioned, gives some hope that this apparently insuperable difficulty will eventually be overcome. We had hoped at the London Hospital to evolve a method of vaccination against small-pox on lines similar to those employed in distemper. My colleague $\mathrm{Dr}$. Bland has carried out a 
number of experiments with this object in view; but his 'efforts so far have not met with success. Formolized vaccine virus, inactive to the extent that serial passage in animals will not reactivate it, has only produced a very low-grade immunity, insufficient to protect even against a comparatively small dose of active virus. This has been a disappointment, but it should stimulate us to renewed effort. Research has given us a method of prophylactic vaccination against the filterable viruses which has proved its value in veterinary medicine, and $I$ am optimistic enough to hope that further work will overcome the difficulties in the way of its exploitation in protecting man against some of the filterable viruses to which he is susceptible.

Passive Immunity.

I mentioned previously that immunity to a filterable virus was associated with the presence of a specific antibody in the blood. The serum of a person, for instance, who has had yellow fever, when mixed with yellow fever virus in suitable relative proportions, will render that virus innocuous for a susceptible animal; it has neutralized it, hence the term neutralizing antibody. But the presence of the antibody can be demonstrated in another way, of which I propose to give you an experimental example.

The guinea-pig is susceptible to the virus of herpes. Implanted in the shaved hairy skin, this virus gives rise to the typical vesicular lesion which charaeterizes human herpes. If one infects a series of guinea-pigs and essays reinfection in them at daily intervals it will be found that seven days or so after infection they can no longer be reinfected; they are immune, and it can further be shown that the onset of this immunity coincides with the appearance of a specific herpetic antibody in the blood. Such an immune guinea-pig can be hyperimmunized by giving it a series of inoculations of living virus, and thereby the neutralizing power of its serum for herpes virus can be considerably increased. Inject $2 \mathrm{c.cm}$. of such a hyperimmune serum into a normal guinea-pig, and twenty-four hours later test its susceptibility to herpes virus. It will be found to react very slightly, if at all, to a dose of virus which produces an intense reaction in an untreated guinea-pig; the guinea-pig has been passively immunized to herpes virus.

This method has its application in human disease, but since one cannot subject individuals to a process of hyperimmunization as was done in the case of the guinea-pig, use has to be made of convalescent serums. In Canada there is full appreciation of the value of the use of convalescent serum in poliomyelitis, but less, perhaps, of the prophylactic use of measles convalescent serum. Serum collected early in convalescence has a considerable antibody content, so much so that when administered up to the fifth day after exposure to infection in doses varying from 1 to $10 \mathrm{c.cm}$. according to the age of the person, it will give complete protection; and the same dosage given later, from the fifth to eighth day after exposure, though no longer protecting against measles, modifies the attack. In children under 2 years old, in whom measles is a redoubtable discase, one aims at giving complete protection; but in older children, unless they are delicate, it is better to give partial protection, for the modified measles is a trivial affair and the patient gets the benefit of acquiring a solid immunity to this disease.

Although this method has its uses in private practice it has its chief applications in children's hospitals and in the children's wards of our large general hospitals. In the Hospital for Sick Children, Great Ormond Street, this method has been applied for some time now, and has proved of the greatest service $T_{t}$ is also in use in the wards of the children's departinent at the London Hospital, and whereas prior to its introduction a case of measles appearing in the ward meant closing the ward to new cases and passing through a period of quarantine, now, the offending case having been dispatched to the fever hospital, the remaining children receive passive protection and the routine of the ward continues uninterrupted. The great drawback is, of course, the difficulty of procuring an adequate supply of convalescent serum. The recent success recorded by Fairbrother ${ }^{12}$ in producing an effective antipoliomyelitis serum in a horse makes one hope that it may not be impossible to produce viricidal serums of effective titre in animals such as the horse, and so become independent of the limited and precarious supply of antiserum which convalescents now provide. But here again, as in the case of active immunization with vaccines, much will depend on the progress made with the problem of cultivation.

\section{Immunity Reactions.}

A valuable aid to diagnosis is given by such methods as the Widal and the complement fixation tests, and since virus infections give rise to specific antibodies one might expect that these same reactions would be of service in this group of diseases also. Experience is showing that this is the case.

Gordon $^{13}$ has shown that with the viruses of vaccinia and small-pox both specific flocculation and complement fixation reactions can be demonstrated, and recent work by Burgess, Craigie, and Tulloch ${ }^{14}$ has demonstrated the practical value of the flocculation test. Small-pox in England is almost entirely of the mild type, the so-called alastrim, and frequently these cases present difficulty in diagnosis. The flocculation test is performed with a specific serum prepared in the rabbit and a suspension of the crusts from the lesions of the suspected case. The use of this test by Burgess, Craigie, and Tulloch during an outbreak of mild small-pox in the South of England and North-Wast England, has shown how very helpful it may be. These investigators examined material from fifty-three cases of small-pox, fifty-two of which were of the mild variety, and in only three of these cases was there any difficulty in interpreting the result of the test. The findings with the flocculation test were checked by comparison with the clinical and epidemiological data, and by the result of vaccination during convalescence; eomplete agreement between the laboratory and field investigations was observed. Further, the crusts from twenty-seven cases of varicella, one case of septic rash, and one of impetigo were examined with entirely negative results.

When it is recalled also that in Great Britain the percentage of the population vaccinated against small-pox is steadily decreasing, it becomes evident that the control of this disease will depend to an increasing extent on the early recognition of cases, and the value of a diagnostic flocculation test as an aid to this cannot be over-estimated. The Bordet-Gengou reaction, or reaction of complement fixation, is also given by an antiviral serum in the presence of the specific virus. Mention has been made of the work of Gordon with vaccinia and small-pox viruses in this respect, and the researches of Netter and Urbain, Wollman, Marie, Ciuca, and others have shown that this reaction can be demonstrated in the case of other filterable viruses as well. At the London Hospital, Dr. Bland and $I^{15}$ have devoted a considerable time to the study of this question, and we have evolved a technique which has given very satisfactory results. The viruses worked with have been those of vaccinia, small-pox, herpes, and zoster; and although much of this work has been carried out with hyperimmune serums prepared in laboratory animals, we have bcen able to demonstrate the same phenomenon with serum from convalescents, though here the reaction is weaker, as one would expect. In the case of the work on zoster, convalescent serums have been used entirely because of the lack of a suitable experimental animal in which to prepare a serum. It is true that difficulties are encountered in performing this test with filterable viruses, and its application is limited in certain directions. For instance, a vaccinia antigen prepared from the brain of a rabbit inoculated intracerebrally with this virus will not, in our hands, give specific fixation of complement, although one can demonstrate that the antigen contains an abundance of active vaccinia virus. And yet this same brain antigen will produce a serum which will give good fixation with an antigen prepared from vaccinial lesions produced in the skin or testicle. The reason for this is obscure and is still being investigated, but despite these occasional anomalous findings, we consider that the reaction is virus-specific and capable of considerable service in practice. I will give some examples.

A case of encephalomyelitis was admitted to the London Hospital under the care of my colleague Dr. W. R. Brain. This patient had an extensive zoster of the head and neck, and. symptoms indicative of involvement of the brain and cord which 
had developed subsequently to the zoster eruption. The question naturally arose whether the encephalomyelitis was due to the zoster virus or not, but since both the vesicle fluid collecied from the cruption and the cerebro-spinal fluid fixed complement in the presence of known zoster convalescent scrums, there was little doubt that the case was in fact ons of zoster encephalomyelitis. It is true that the reaction given by the cerebro-spinal fluid was not as strong as that obtained with the vesicle fluid, but it was nevertheless quite definite, and cerebro-spinal fluids from cases of encephalomyelitis complicating diphtheria and scarlet fever gave entirely negative results.

Recently I have had the opportunity of examining the serum of individuals who had recovered from psittacosis for the presence of specific complement-fixing antibodies, and here again $I$ have obtained evidence of a specific reaction. Psittacosis may not be so rare a condition as is imagined, and apart from extensive outbreaks like the recent one, where the number and severity of the cases inevitably attracted attention, sporadic cases probably occur from time to time and pass umnoticed. The inoculation of animals is too slow a method to be of practical use as a diagnostic procedure, and a specific serum reaction would be a great help in clearing up the diagnosis.

It may be said that the examples given are both of rather rare conditions, but the principle is nevertheless of general application. In this brief and rather sketchy survey of the present position of rescarch in the realm of filterable viruses an attempt has been made to show that something of practical import has been achieved. Undoubtedly an enormous amount remains to be done, but the number of workers in this field is steadily increasing, and on every hand a determined effort is being made to gain a clearer understanding of this group of viruses. Some of the problems seem almost insoluble, but it must not be forgotten that the commonplace in bacteriology to-day must have appeared equally obscure to those who preceded Pasteur.

1 Olitsky, P. K., and Gates, F. L. : Journ. Exper. MLel., 1922, 26, 501. Mills, K. C., Shibley, G. S., and Dochez, A. R. : Ibid., 1928, 4\%, 193. ${ }^{3}$ Steinhard, E., and Lambert, R.. A. : Journ. Infect. Dis., 1914, 14, 87. 5 Parker, F., and Nyc, R. N.: Amer. Journ. Path., 1925, 1, 3<5.

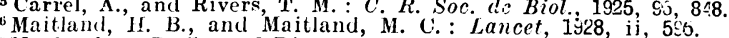
7 Muckenfuss, R. S., and Rivers, T. M. : Journ. Exper. Med., 19:0, 51, 149 Dochez, A. R., Shibley, G. S., and Mills, K. C. : Proc. Soc. Exper. Biol. and Hed $1929,26,562$

Vallée Hed., 1929, 26, 562. Binjard, $\mathrm{P}$. Rev gen de mié Vallée,

${ }^{10}$ Bedson, S. P., Maitland, H. B., and Burbury, T. M. : Journ. Comp. Path. and Ther., 1927, $40,1$.

11 Laidlaw, P. P., and Dunkin, G. W. : Ibid., 1928, 41, 1 and 209. 12 Fairbrother, R. W. : Brit. Journ. Exp. Path., 1930, 11, 43

${ }^{13}$ Gordon, M. H. : Medical Research Council, Special Report Scries, No. 88, 1925 .

11 Burgess, W. L., Craigie, J., and Tulloch, W. J. : Ibid., 1928. No. 143.

Brdson, S. P., and Bland, J. O. W. : Brit. Journ. E'rl. P'ath., 1929, 10,

\section{MIGRATION AND HEALTH."}

$$
\text { BY }
$$

J. S. PURDY, D.S.O., M.D., C.M., D.P.H., F.R.S.ED., F.R.G.S.

METROPOLITAN MEDICAL OFFICER OF IIEALTI, SYDNEY, NEW SOUTH WALE 3 .

To-DAY the distribution of the white population throughout the British Empire is so important that it warrants consideration not only from an economic and social point of view, but also from the point of view of health.

It is perhaps as necessary for Great Britain as for any country other than 'Japan to organize emigration on an extensive scale, on account of over-population. After or during every great war, there appears to have been a "stocktaking." Thus, after the South African war, the English Inter-Departmental Committee in 1904 showed that sections of the people, more especially in the more congested centres of population, were liable to suffer from the ill effects of overcrowding, or an artificial, unnatural environment. As a matter of fact, there was no evidence of actual physical deterioration, since no previous standard for comparison existed.

Actually the average span of life has advanced ten years during the present generation; and man to-day has excelled

${ }^{*}$ A paper contributed to the Section of Medical Sociology and
History of Medicine at the Annual Meeting of the British Medical History of Medicine at the
Association, Winnipeg, 1930 . in feats of physical endurance and established records surpassing those of earlier periods. We do know, however, that a considerable proportion of people are below an optimum of health and efficiency, physical, mental, and moral. Conscription in Great Britain, the United States, and New Zealand, during the later stages of the war, brought to light some startling statistics. Although it is possible to prove anything by statistics-even the truth-yet it is certainly disquieting to learn that " in the average, out of every nine men of military age in Great Britain, only three were found fit; two were upon a definitely infirm plane of health ; three were incapable of undergoing any extra exertion, being practically physical wrecks; and the remaining man was a hopelessly chronic invalid." In Great Britain alone, a million men examined at the recruiting depots were found to be not sufficiently fit to be worth training for war service owing to structural defects or organic disease.

In regard to conditions to-day, the following passage occurs in Mr. and Mrs. Sidney Webb's monumental work, The History of the Poor Law:

"Is there any condition more sordidly tragic than the lot of the youthful unemployed-to-c'ay counted by the hundred thousand, under-nourished, physically undereloped, empty-minded, lounging in disconsolate gruaps at stre st corners, or aimlessly tramping from one cesual ward to another-a prey to all evil intluences?"

In Australia and New Zealand, although the conditions under which the masses live are vastly better than in Great Britain, still it is comforting to read the statement of the late Professor Cunningham, the distinguished anthropoloc ist :

"In spite of the marked variations which are scen in the physique of the different classes, anthropologists believe, with good reason, that there is a mean physical standard, which is the inheritance of the people as a whole, and that no matter how far certain sections of the people may deviate from this by deterioration, the tendency of the race as a whole will always be to maintain the inherited mean. In other words, those inferior bodily characteristics which are the resuit of poverty (and not vice, such as syphilis and alcoholism), and which are therefore acquired during the lifetime of the individua!, are not transmis sible from one generation to another. To restore, thrrefore, the classes in which this inferiority exists to the mean standard of national physique, all that is required is to improve the conditions of livine, and in one or more generations all the ground that has been lost will be recovered."

\section{The Anzacs.}

Together with the sister overseas Dominions of Canadx and South Africa, Australia and New Zealand offer a field for studying the effects of what is or ought to be generally a healthy and natural environment on a people, for the most part at least, only one or more generations removed from the parent stock of the British Isles, or, in the cuse of parts of Canada and South Africa, people from France and Holland. Sufficient data have already been collected with regard to school children to show that the improved environment has had a beneficial effect. Records collected by the late Mr. Symons and myself for the New Zealand Health Department in 1908 and 1909 - quite as extensive as to numbers examined as the data available to witnesses at the time of the InterDepartmental Committee-were especially interesting in showing that, while the average stature at the ages of 11 to 12 of boys in the public schools in England in 1883 was 54.98 inches, that of the cadets of the Auckland Grammar. School and King's College was 56 inches at the same age. Contrasting the heights of boys at Marlborough College, England, with those of King's College, Auckland, and Wanganui College, we found that between the ages of 14 and 15 the figures were 61.96 for the famous English public school and 63 for the New Zealand schools. Even more interesting was the fact that a comparison between the boys of the Chapel Street School, Auckland (probably the children of the poorest parents of the largest New Zealand city), with the boys of Remuera (the wealthiest suburb), showed less disparity than the measurements and weights of children in the poorer districts of English cities as compared with the children of the more prosperous parents residing in the suburban centres and the boys of the English public schools. Such a result was only to be expected in a country where there is not the severe handicap of poverty-such a dead weight in some of the congested centres of Great Britain. Moreover, the prowess of the young Australian and New 